\title{
Stakeholder Engagement: Methods of Inclusion in South Carolina State Water Plan Decision-Making
}

\author{
Thomas Walker III ${ }^{1}$, C. Alex Pellett² ${ }^{2}$ Jeffery Allen ${ }^{3}$
}

AUTHORS: ${ }^{1,3}$ South Carolina Water Resources Center, Clemson Public Service and Agriculture. 509 Westinghouse Road. Pendleton, SC 29670. 2South Carolina Department of Natural Resources, P.O. Box 167, Columbia, SC 29202.

\begin{abstract}
Stakeholder engagement in natural resource planning has become increasingly important at local and state levels. Including stakeholders in decision-making can increase buy-in and public support of final regional and state recommendations. It can also lead to policy change and improved implementation outcomes resulting from these planning processes. South Carolina is developing a stakeholder-driven water plan, although it is several years away from being finalized. The methods used in this process are a departure from past efforts. Stakeholder inclusion in decision-making in the water planning process is described and analyzed in this article. The focus is on the specific phases of the process and the methods of inclusion used or those anticipated to be used. In this cycle, stakeholder involvement in decisions range from informational/advisory to consultative to decision-making.
\end{abstract}

\section{INTRODUCTION}

The process of developing a new state water plan has been underway for several years in South Carolina (SC). Water planning cycles are an adaptive management technique to enhance natural resource management. Natural resource management is not static, and planning, in response, must be adapted accordingly. The process has been divided into distinct phases to break it into manageable projects. The phases are:

- Surface Water Availability Assessment,

- Groundwater Availability Assessment,

- Water Demand Projections,

- Regional Water Plans, and

- State Water Plan. (Rentiers, 2018)

Decision-making is a critical step in the process of resource management and planning. The agency with legal authority for water planning is the South Carolina Department of Natural Resources (SCDNR) (SC Code Ann., Section 49-3, 1993). Additionally, SCDNR is required to provide recommendations to state Executive and Legislative branches to inform water policy decisions (SC Code Ann., Section 49-3, 1993). The agency with legal authority to enforce water regulations in the state is the South Carolina
Department of Health and Environmental Control (SCDHEC). During past planning cycles in SC, the approach to writing the state water plan was much less inclusive. The SC state water plan of 2004 was a significant step toward modern water planning. It includes recommendations for the state in regard to water planning, policy, and regulatory needs to ensure adequate resources in times of drought and in the future (Badr et al., 2004). While some recommendations from the plan have been implemented, it is possible that the outcome could have been improved by a more inclusive, participatory planning process. The need for a participatory model for water planning has been recognized (Badr et al., 2004), and stakeholders from various in-stream and offstream use sectors have been included in decision-making throughout the current planning cycle. All water planning stakeholder meetings are open to the public and follow public notification law.

The goal of participatory decision-making in water planning is to include stakeholders in various ways for an improved plan and for stakeholder support of the plan. Therefore, stakeholder identification and inclusion is an important consideration. Water users are an identified group of stakeholders to include in planning processes (e.g., agriculture, energy, manufacturing, public and domestic water supply, golf, mining, aquaculture, livestock). Other stakeholders, which have been identified as affected by or 
interested in water planning decisions, include councils of government, government employees at all levels, conservation groups, environmental groups, recreational users, concerned citizen groups, well drillers, researchers, and the general public. Additionally, strategic inclusion of influential stakeholders to garner sectoral and political support is also prudent, especially in inclusive shared decision-making capacities. It is too early in the process to assess outcomes of stakeholder inclusion.

This paper discusses the phases of the planning process to this point in the water planning cycle. With a broad goal of high participation in the decision-making process among water stakeholders as a target in SC water planning, discussion will focus on the participatory decision-making nuances of each phase. The surface water assessment (phase 1) was completed in 2017. There are several phases of the process running concurrently. The groundwater assessment (phase 2) is nearing completion. The water demand projections (phase 3) has finished the methodology development portion of the process after a period for public comment was held. A series of stakeholder meetings will be held to present these water demand projection methods. The methods will then be applied to various water use sectors to derive projections beginning with the Edisto basin. Remaining basin projections should be completed in 2020. Additionally, the process of developing a framework document is in progress for developing regional water plans.

The surface water availability assessment meetings were held throughout the eight regulatory basins in SC. The eight basins are used by SCDNR to promote continuity between water planning and water regulation by SCDHEC. These basins are: Broad, Catawba, Edisto, Pee Dee, Salkehatchie, Saluda, Santee, and Savannah (SCDHEC, "SC Watershed Atlas"). The first round of surface water meetings began in the Saluda basin in April of 2015 and concluded in the Savannah basin in August of 2016.

The groundwater availability assessment meetings were held in the inner and outer coastal plain areas of the state in November and December of 2017 (Walker et al., 2018). The coastal plain regions of the state begin at the fall line, which begins at approximately the middle of the state. The piedmont area of the state was not included in the groundwater assessment due to significantly less groundwater quantity and use.

The water demand projections methodology technical advisory committee (TAC) consisted of a more fluid group of sectoral experts. The TAC provided significant knowledge of offstream water use at the local level. Six meetings were held to develop water demand methodology for offstream uses and were held from August to November of 2018.

In 2018, the State Water Planning Process Advisory Committee (PPAC) was organized to develop the regional water planning framework document to guide River Basin
Councils (RBCs) in the development of regional water plans. The PPAC has been meeting monthly to discuss and detail various components of the framework document so that regional water planning can be successful and congruent. The Edisto RBC is anticipated to be formed in late 2019 and early 2020 as a pilot basin.

\section{LITERATURE REVIEW}

There is a growing body of literature describing inclusive, participatory, and collaborative approaches to resource management. Agencies with legal authority for water management and planning are increasingly seeking stakeholder involvement to encourage buy-in and ownership of the policy process (Sabatier et al., 2005). This has the potential to improve implementation outcomes due to perceived stakeholder legitimacy of the planning process (Sabatier et al., 2005).

Implementation research has primarily focused on the question of why implementation has failed rather than succeeded (Pressman and Wildavsky, 1984). This research has thus influenced decision-making as to promote inclusive decision-making processes to improve implementation outcomes. As a result and where appropriate, planning has become more bottom-up than top-down, allowing those at the local level to provide feedback on assumptions and models (Sabatier et al., 2005; Koebele, 2015).

The problem of identifying stakeholders and deciding who, to what degree, and when in the process stakeholders participate is of equal importance (Cowie and Borrett, 2005). Stakeholders generally fall under a broad definition of those who are responsible for or affected by the decision (Cowie and Borrett, 2005). Stakeholders can then range from agency personnel, to those groups and sectors that use water resources, or to the public in general.

Desired outcomes require varying degrees of stakeholder inclusion (Cowie and Borrett, 2005). Stakeholder involvement can lengthen the planning process and may require additional funding as the agencies are asked to do more to develop collaborative water plans.

An extended review of inclusive resource management literature was conducted during the groundwater assessment phase of the planning cycle. The conclusions of that review provide additional support for the importance of stakeholder inclusion in water resource decision-making (Walker et al., 2018).

\section{METHODS}

\section{STAKEHOLDER ENGAGEMENT}

Briefly mentioned in the literature review, the type of stakeholder inclusion method used in decision-making is dependent on the identified outcomes of the process. A 
sliding decision-making scale of stakeholder involvement can lead to significantly different outcomes with each approach becoming more inclusive than the last (Cowie and Borrett, 2005). The sliding decision-making scale types are notification, advisory, consultative, and decision-making (Cowie and Borrett, 2005).

Decision-making in SC water planning phases and anticipated phases have taken on several forms of this sliding scale. Figure 1 applies the SC water planning phase processes to the Cowie and Borrett (2005) decision-making scale along the X-axis. The method used in Quick and Feldman's (2011) study was observable stakeholder processes based on levels of participation (low to high) and inclusion in decision-making (low to high). The low to high measurements were adapted and applied to both the $\mathrm{x}$-axis and the $\mathrm{y}$-axis. Similarly, the process in SC has taken on various forms of participation and inclusion. To simplify the figure, placement of the processes was generally where the process fits within the context of participation and inclusion.

The surface water methods could be described as notification/advisory; stakeholders were informed and information was gathered regarding stakeholder perceptions (Figure 1). The surface water assessment also had a TAC consisting of 11 surface water stakeholders involved in a consultative process (SCDNR, 2015). Similarly to the surface water meetings, groundwater stakeholder methods followed an information/advisory decision-making stakeholder format (Figure 1). The groundwater assessment also has a TAC of groundwater use experts consisting of 6 members that again were consultative in the decision-making process of groundwater modeling efforts (SCDNR, 2018). The water demand TAC used a high participation and high inclusion method in that the TAC was developing the methodology for water demand projections, which is a consultative/decisionmaking approach. The PPAC, with the collaborative nature of this process, is a decision-making method in its approach with fewer participants in order to deliver a framework document in a timely manner.

\section{EVALUATION OF STAKEHOLDER INVOLVEMENT}

South Carolina Water Resources Center researchers have continued to be involved in all phases of the planning process and have continued quantifying the number of stakeholders who participated in the processes and gathering data on their affiliations. iClickers, an information-collection tool, were used to collect anonymous attendee data during the surface water and groundwater availability assessment stakeholder meetings. Stakeholder organizational type categories were broad in the surface water and groundwater meetings due to the data-collection device. Additionally, organizational category types evolved slightly from the surface water meetings and the groundwater meetings (Appendix 1; Appendix 2). Attendance records and affiliations were kept for the water demand projection TAC meetings as well. These stakeholder affiliations were categorized into broader types of water users. The surface and groundwater TACs and the PPAC have stakeholders who were appointed by SCDNR with no end date known at the time of this paper.

\section{RESULTS}

Results of the methods of engagement are presented in two ways: (1) by participation in terms of numbers of stakeholders engaged, and (2) from sectors of water

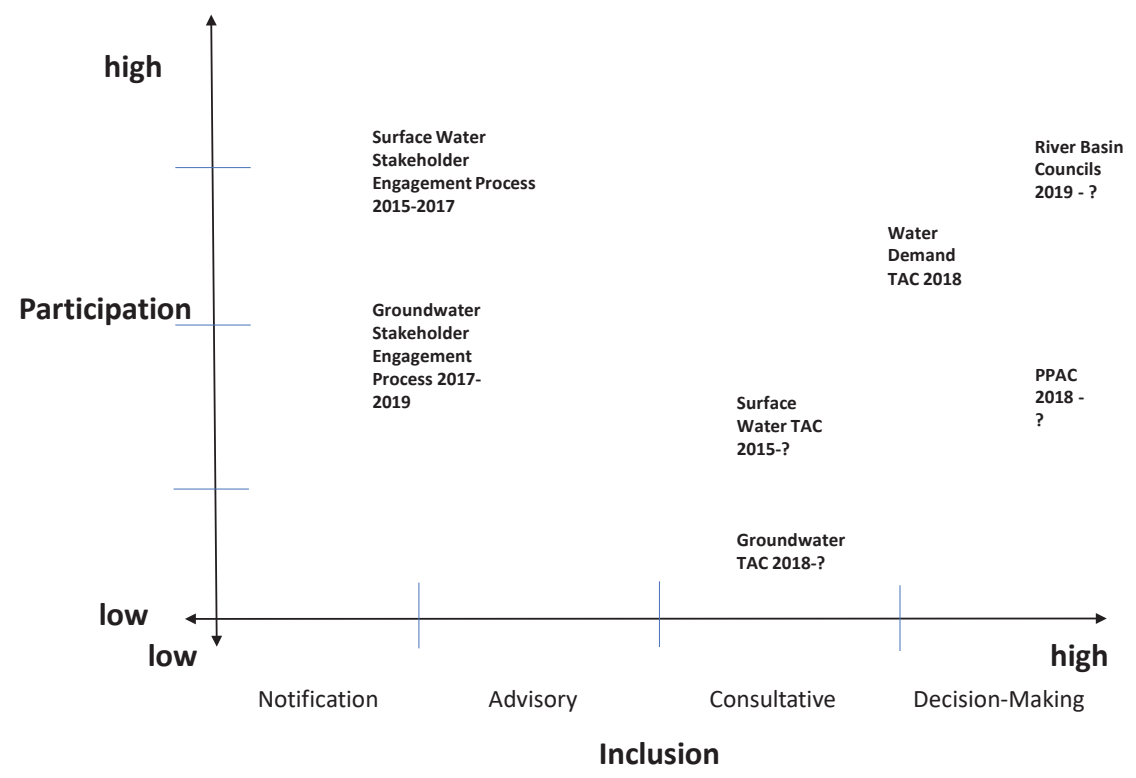

Figure 1. Methods of stakeholder participation and decision-making inclusion in the current SC state water planning cycle. (Adapted from Cowie and Borrett, 2005; Quick and Feldman, 2011.) 


\section{Methods of Inclusion in South Carolina State Water Plan Decision-Making}

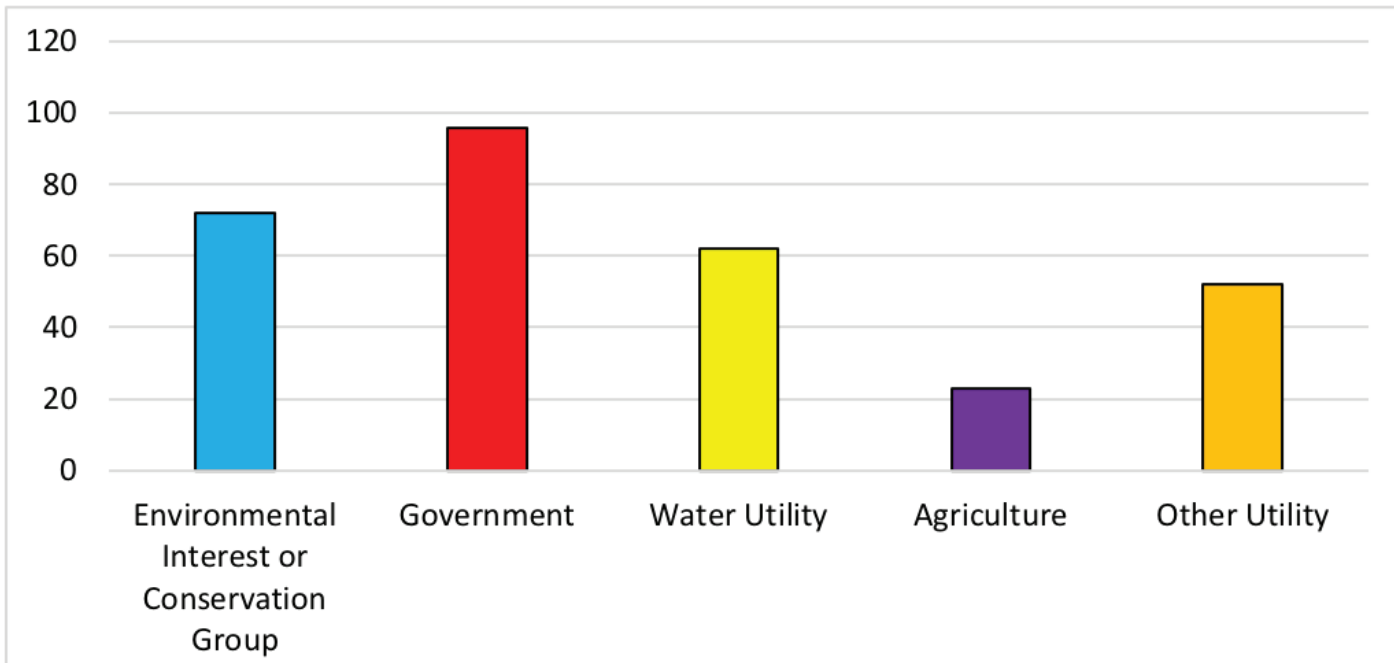

Figure 2. Stakeholder organizational type representation across 8 surface water basins in SC.

use stakeholders represented. The tables in the appendix referenced in the results section provide the quantitative numbers that correlate to Figures 2 through 4 .

\section{SURFACE WATER ASSESSMENT}

The surface water meetings saw participation and inclusion in the surface water availability assessment from 360 stakeholders. Not all stakeholders responded to all iClicker questions in the meetings. Of the 360 stakeholders who attended, 305 responded to the question about the type of organization they represent (Appendix 1). Government was the highest-represented stakeholder across all 8 basins (Figure 2). Stakeholder participation and inclusion primarily followed a panel discussion and question and answer format after presentations providing feedback on the surface water model.

\section{GROUNDWATER ASSESSMENT}

The two first-round stakeholder meetings in November and December of 2017 drew 55 stakeholders (Appendix 2 ). As groundwater availability is primarily a concern in the coastal plain, it drew fewer stakeholders in addition to holding fewer meetings. Groundwater stakeholders were most highly represented by industry or utility (Figure 3 ). Stakeholder participation was primarily a question and answer session after the presentations providing feedback on the groundwater flow model.

\section{WATER DEMAND PROJECTIONS}

The Water Demand Projections TAC had members who attended all water demand meetings, but many attended the sectoral meeting that matched their respective water use

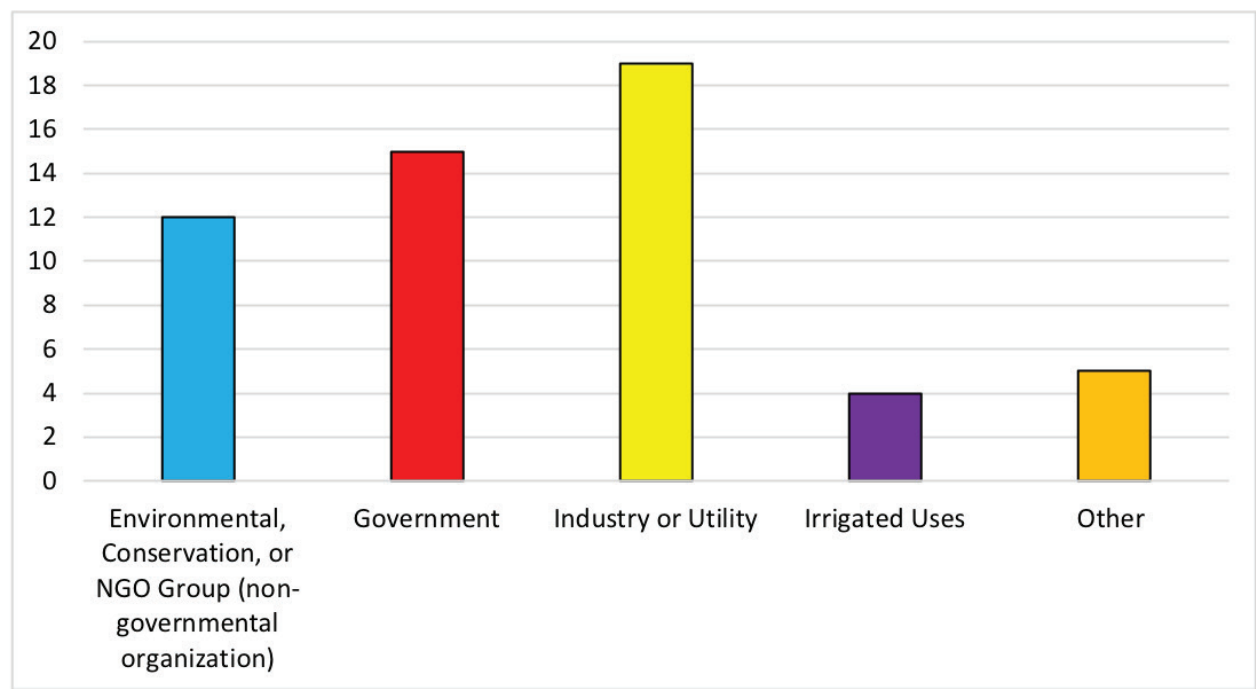

Figure 3. Stakeholder organizational type representation across groundwater inner and outer coastal plains in SC 


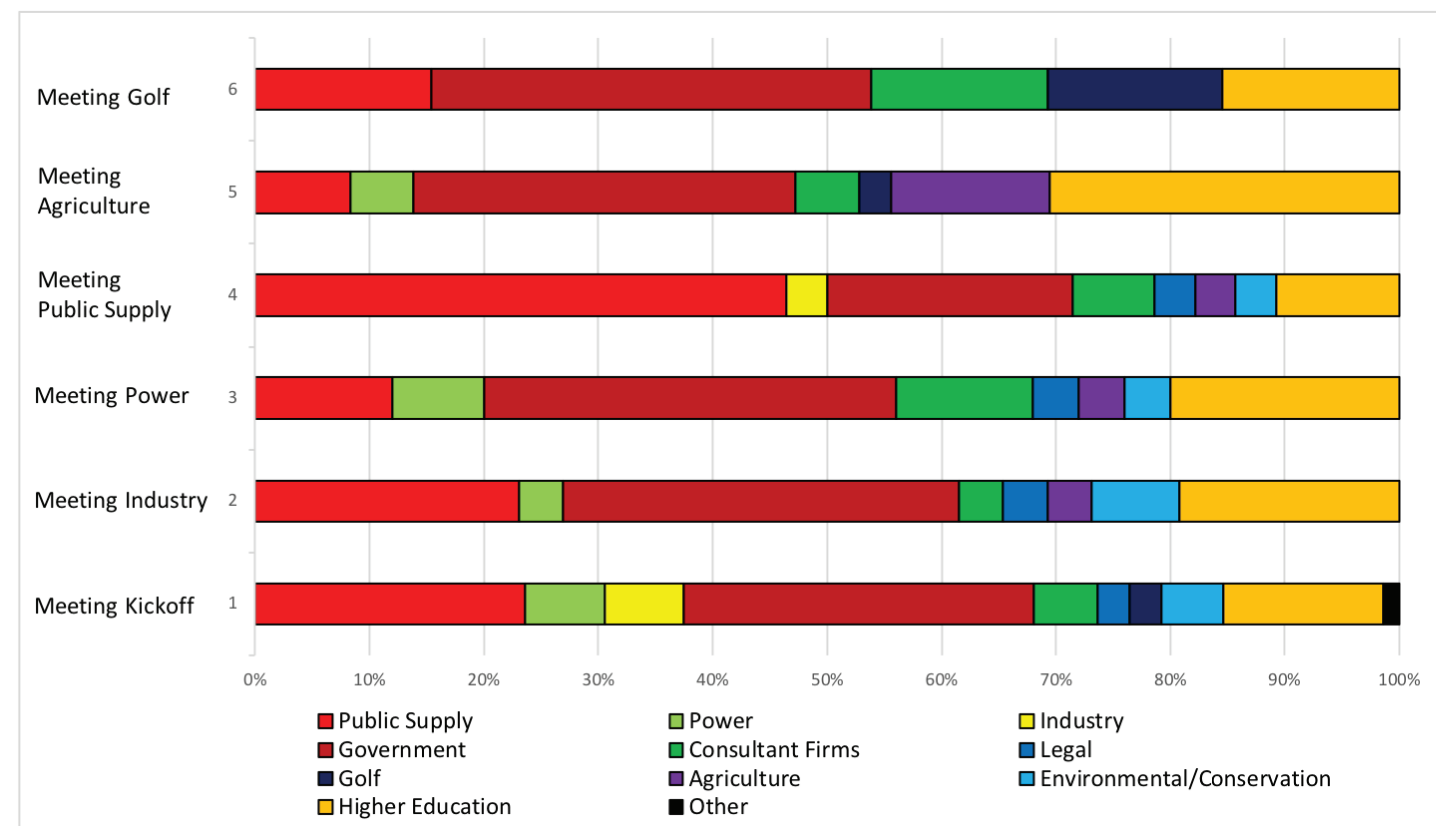

Figure 4. Stakeholder organizational type representation in the water demand projection methodology TAC.

sector. Overall, 110 unique stakeholders attended the water demand methodology meetings (Appendix 3). A more detailed analysis of organizational representation was collected due to the meeting style, which was facilitated through Webex online meetings (Cisco Webex, 2019; Figure 4). Webex is a video conferencing and meeting platform that allows hosts and participants to be in separate locations, creating a virtual meeting space to collaborate. The sectoral draft methods were presented, followed by TAC discussion. After a finalized draft was distributed and final TAC feedback incorporated, the water demand methods were open to a public comment period. The water demand projection methods will be presented at stakeholder meetings and began in fall 2019.

\section{PLANNING PROCESS FRAMEWORK}

The PPAC has 19 stakeholders, a facilitator, and a coordinator for the process and follows a charter, which standardizes group norms (Rentiers, 2018; Clemson PSA, 2019). These stakeholders were invited to participate by SCDNR, many of which have participated in past technical advisory capacities in the water planning process. The entities that comprise the PPAC are:

- public water suppliers (Greenville Water, Mount Pleasant Waterworks, and Anderson Regional Joint Water System),

- public water supply associations (South Carolina Rural Water Association and Water Environment Association of South Carolina/South Carolina Section of the American Water Works Association),

- energy utilities (Duke Energy and Santee Cooper),

- Catawba-Wateree Water Management Group,
- Clemson University South Carolina Water Resources Center,

- The Dunes Golf and Beach Club,

- Upstate Forever,

- The Nature Conservancy,

- SCDHEC,

- SCDNR,

- Congaree Riverkeeper,

- WP Rawl farm,

- Weathers farm,

- and two citizen representatives.

The PPAC is tasked with creating a state water planning framework document to guide RBCs. The PPAC and RBCs have and will continue to have diverse stakeholder representation, which not only could improve implementation outcomes but also prevent one sector or one interest from dominating the processes. Currently, the PPAC draft state water planning framework sets a maximum of 25 voting members with 8 identified stakeholder categories for the RBCs. The 8 categories are: agriculture, forestry, and irrigation interests; local governments, water and sewer utilities; electric-power utilities and non-federal reservoir operators; industry and economic development interests; water-based recreation interests; environmental interests; and at-large water-based interests. The PPAC was organized into 15 subcommittees to address identified issues for the $\mathrm{RBC}$ process, which are incorporated in the draft framework (Appendix 4). Once a final draft of the framework is 


\section{Methods of Inclusion in South Carolina State Water Plan Decision-Making}

complete, the PPAC will rank the framework in accordance with the PPAC charter to finalize it. The PPAC will continue to reconvene, as needed, in future planning cycles to advise RBCs and review RBC plans.

\section{DISCUSSION}

Water planning in South Carolina is making significant progress toward creating a bottom-up stakeholder-driven water plan. True stakeholder-driven processes take significant time to complete. Previous and current phases of the water planning cycle have engaged diverse groups of stakeholders. The PPAC is developing the framework as comprehensively as possible to guide both the RBCs and the process at the regional planning level. Once the draft framework is finalized, SCDNR will organize the RBCs as appropriate within the water planning cycle timeline. It is anticipated that the RBCs will have significant decision-making capabilities in developing regional water plans for each of the 8 river basins, with guidance from the framework document for regional water plans. Widespread participation and inclusion in the decision-making process will involve stakeholders who may not have participated in other phases of the planning process. The result would be a significant stakeholder-driven process (Figure 1; Figure 2). Limitations of this research include pursuing qualitative research to understand stakeholder perceptions of how their inclusion may impact legitimacy and support of the river basin plans and state water plan. After the pilot basin is complete, qualitative research is necessary to potentially reveal strengths and weaknesses in the process for future basins and its future iteration.

Water issues are local. As such, a bottom-up approach to regional water planning is an important development in state water planning in South Carolina. While there are possibly larger state water resource management issues that must be addressed in the state water plan, allowing those who use the water daily to take ownership of the RBC decision-making process and develop regional water plans could encourage buy-in and better implementation outcomes at the local level. To that end, it would serve future water planning cycles well and would help to address any implementation issues that arise to keep the PPAC or a state steering committee and RBCs together as that organizational knowledge and those relationships will be well established and important moving forward.

Even after the RBC process and regional water planning process are completed and the state water plan is updated, it may take several years to analyze implementation and management outcomes within the river basins and at the state level. The water plan is required legally to be updated every five years. It could take that long after the update to determine success of this round of state water planning. Another test for this water planning process could be during major drought in this region of the country. The research is incomplete, as the $\mathrm{RBC}$ regional water planning phase and update of the state water plan will continue well into the future for this water planning cycle.

\section{REFERENCES}

Badr AW, Wachob A, Gellici J. 2004. South Carolina water plan. 2nd ed. Columbia (SC): South Carolina Department of Natural Resources.

Clemson PSA. 2019. State Water Planning Process Advisory Committee (PPAC). www.scwatermodels.com.

Cisco Webex Telecommunication Software. 2019.

Cowie GM, Borrett SR. 2005. Institutional perspectives on participation and information in water management. Environmental Modelling and Software, 209(4):469-483. https://doi.org/10.1016/j.envsoft.2004.02.006.

Koebele EA. 2015. Assessing outputs, outcomes, and barriers in collaborative water governance: a case study. Journal of Contemporary Water Research \& Education, 155(1):63-72. https://doi.org/10.1111/j.1936704X.2015.03196.x.

Pressman JL, Wildavsky A. 1984. Implementation. 3rd ed. Oakland (CA): University of California Press.

Quick KS, Feldman MS. 2011. Distinguishing participation and inclusion. Journal of Planning Education and Research, 31(3):272-290. https://doi. org/10.1177/0739456X11410979.

Rentiers K. 2018. Plenary session: water planning and water science. South Carolina Water Resources Conference. Columbia, South Carolina.

Sabatier PA, Focht W, Lubell M, Trachtenberg Z, Vedlitz A, Matlock M. 2005. Swimming Upstream: collaborative approaches to watershed management. Cambridge (MA): MIT Press. Chapter 1, Collaborative approaches to watershed management; p. 3-22.

SC Code of Laws. Title 49 Chapter 3: Water Resources Planning and Coordination Act. 962 Code Section 70-21; 1967 (55) 60; 1993 Act No. 181, Section 1244.

SCDHEC. 2019. SC Watershed Atlas. https://gis.dhec. sc.gov/watersheds.

SCDNR. 2015. Surface Water TAC minutes. http://www.dnr. sc.gov/water/waterplan/surfacewater.html.

SCDNR. 2018. Groundwater TAC minutes. http://www.dnr. sc.gov/water/waterplan/groundwater.html.

Walker T, Dickes, L, Allen J. 2018. South Carolina groundwater availability assessment: 2017 stakeholder outreach and engagement results. Journal of South Carolina Water Resources, 5(1):45-59. https://doi. org/10.34068/JSCWR.05.04. 


\section{ApPendix 1: \\ Stakeholder Representation Type at 8 Basin Surface Water Stakeholder Engagement Meetings}

\begin{tabular}{lcc}
\hline \multicolumn{1}{c}{ Stakeholder Organizational Type $(\mathbf{n}=\mathbf{3 0 5})$} & Count & Percent $(\%)$ \\
\hline Environmental interest or conservation group & 72 & 23.607 \\
Government & 96 & 31.475 \\
Water utility & 62 & 20.328 \\
Agriculture & 23 & 7.541 \\
Other utility & 52 & 17.049 \\
\hline
\end{tabular}

\section{APPENDIX 2:}

Stakeholder Representation at Groundwater meetings: Inner and Outer Coastal Plains of SC

\begin{tabular}{lcc}
\hline \multicolumn{1}{c}{ Stakeholder Representation Type $(\mathbf{n}=\mathbf{5 5})$} & Count & Percent (\%) \\
\hline Environmental, conservation, or NGO group & 12 & 21.818 \\
(nongovernmental organization) & & \\
Government & 15 & 27.273 \\
Industry or utility & 19 & 34.545 \\
Irrigated uses & 4 & 7.273 \\
Other & 5 & 9.091 \\
\hline
\end{tabular}

\section{ApPendix 3:}

Stakeholder Representation of the Water Demand Projection Methodology TAC (Technical Advisory Committee; $N=110$ )

\begin{tabular}{|c|c|c|c|c|c|c|c|c|c|c|c|c|c|c|}
\hline Meeting & Date & Agenda Topic & Count & $\begin{array}{l}\text { Public } \\
\text { Supply }\end{array}$ & Power & Industry & $\begin{array}{c}\text { Govern- } \\
\text { ment }\end{array}$ & $\begin{array}{l}\text { Consultant } \\
\text { Firms }\end{array}$ & Legal & Golf & $\begin{array}{l}\text { Agri- } \\
\text { culture }\end{array}$ & $\begin{array}{c}\text { Environmental/ } \\
\text { Conservation }\end{array}$ & $\begin{array}{l}\text { Higher } \\
\text { Ed. }\end{array}$ & Other \\
\hline 1 & $8 / 1 / 18$ & $\begin{array}{c}\text { Introduction and } \\
\text { Orientation "Kickoff" }\end{array}$ & 73 & 17 & 5 & 5 & 22 & 4 & 2 & 2 & 0 & 4 & 10 & 1 \\
\hline 2 & $8 / 15 / 18$ & $\begin{array}{c}\text { Industry/ Manufacturing } \\
\text { Sector }\end{array}$ & 26 & 6 & 1 & 0 & 9 & 1 & 1 & 0 & 1 & 2 & 5 & 0 \\
\hline 3 & $8 / 29 / 18$ & Power Sector & 25 & 3 & 2 & 0 & 9 & 3 & 1 & 0 & 1 & 1 & 5 & 0 \\
\hline 4 & $10 / 10 / 18$ & Public Supply Sector & 28 & 13 & 0 & 1 & 6 & 2 & 1 & 0 & 1 & 1 & 3 & 0 \\
\hline 5 & $10 / 24 / 18$ & $\begin{array}{c}\text { Agricultural Irrigation } \\
\text { Sector }\end{array}$ & 36 & 3 & 2 & 0 & 12 & 2 & 0 & 1 & 5 & 0 & 11 & 0 \\
\hline 6 & $11 / 7 / 18$ & $\begin{array}{c}\text { Golf Course Irrigation } \\
\text { Sector }\end{array}$ & 13 & 2 & 0 & 0 & 5 & 2 & 0 & 2 & 0 & 0 & 2 & 0 \\
\hline
\end{tabular}




\title{
APPENDIX 4: \\ PPaC Subcommittees in the South Carolina State Water Planning Framework
}

\author{
Subcommittee \\ Process of Designating Members to River Basin Councils \\ Roles and Responsibilities of the River Basin Councils \\ Roles and Responsibilities of the State Agencies \\ Roles and Responsibilities of Outside Contractors \\ Databases and Models that must be Utilized in the Development of Regional Water Plans \\ Council Bylaws \\ Regional Water Plan Format and Table of Contents \\ Public and Stakeholder Notification and Participation \\ Financing of Regional Water Plans \\ Implementation of Regional Water Plans \\ Outline of how the Regional Water Plans fit into the State Water Plan \\ Other Administrative Rules \\ -How to Handle Conflict Between Two Basins \\ -Metrics of Success \\ Water Demand Projections-Corrective Actions for Shortages/Drought Response \\ Continuing Roles of River Basin Councils \\ Drought Response
}

